\title{
Nationalism and Internationalism in Liberalism, Marxism and Islam
}

\author{
By Tahir Amin. Islamabad: IIIT, 1991. xxxii + 106 pp.
}

Professor Amin, who teaches international relations at Quaid-i-Azam University in Islamabad, has provided us with a short but insightful analysis of twentieth-century writings from the Liberal, Marxist, and Islamic traditions on the issue of "nationalism versus internationalism." Pointing out that Westem writings treat the "nation-state" as "a universal form," he presents two main arguments: a) nationalism emerged from "Western liberal culture" and is now "seriously challenged by a variety of communitarian internationalisms," of which Islamic revivalism is the most important in the Islamic world (p. 5), and b) Islamic revivalismoften misunderstood as being a backward-looking "fundamentalism" -is "a reaction against Liberal and Marxist internationalism which are seen as the two imperialist ideologies of the West" (p. 6).

Amin briefly states the essence of the three traditions-the Liberal belief in nationalism as natural, with "world unity [envisaged as emerging] through the prism of nation-states" (p. 7); the Marxist goal of a "classless world society" (p. 7); and the Islamic idea of all "believers . . . belong[ing] to one global community, the ummah" (p. 10). Insisting that the dialogue among the three trends is facilitated by understanding all of them "from within and through their main spokesmen" (p. 10), he proceeds with a chapter on the representative literature of each. Each chapter is divided into three sections: traditional writers, modernization theorists, and postmodernization theorists.

Perhaps reflecting the author's Western education, the book's longest chapter is the one on Liberalism. He begins with Toynbee, whom he describes as "an internationalist par excellence in the Westem communitarian tradition" (p. 13). Three other Liberal writers are categorized as "traditional" - E. H. Carr, Hans Kohn, and Carleton Hayes. Under the designation of modemization theorists, Amin deals with Karl Deutsch and Ernest Gellner, while the section on post-modemization theorists looks mainly at Walker Conner and A. D. Smith.

In the chapter on Marxism, Amin analyzes Marx and Engels as "traditional writers." Lenin is classified as a "modernization theorist," while 
the "national socialists" are Karl Renner and internationalists like Trotsky. Finally, Stalin, Mao Zedong, Immanuel Wallerstein, Michael Hechter, and Tom Nairn are considered, for reasons that are not always clear, as "postmodernization theorists."

In the Epilogue, Amin points to the fundamental similarity of Liberalism and Marxism. This is seen in two instances: a) their shared Western ethnocentrism and, in the case of each camp's modernization theorists, b) an acceptance of nationalism in the belief "that history is moving toward internationalism" and that there is a "dichotomy between tradition and modernity" (p. 81). The latter view is accompanied by the idea that modernity would eventually displace religion, a view that modernization writers in each tradition no longer regard as true.

The chapter on Islam begins with a relatively extensive treatment of Muhammad Iqbal-"the pioneer of contemporary Islamic resurgence" ( $p$. 64) - as a "traditional writer." The author shows that Iqbal advocated a "Pan-Islam [that] means pan-humanism", "couched in the framework of Islamic communitarian perspective" but with the intent "to unite and organize mankind despite all its national distinctions" (p. 65). He also states that Iqbal rejected nationalism "as an alien idea and as antithetical to religion" (p. 66), even as an idea that "displaces religion" and leads to imperialism (p. 67), while seeing it as "a double-edged sword which could also be used to overthrow the yoke of Western imperialism" (p. 68). Although Amin does an excellent job of stating Iqbal's outlook, I wonder why no other "traditional" writer is discussed. I am also a bit puzzled about the criteria used for classifying Iqbal as a "traditional" writer. Jamāl al Dīn al Afghānī, who one has trouble seeing as a representative of a "traditional" outlook, is briefly considered as a precursor of Iqbal, but is understandably not given more attention since this study focuses on twentieth-century writers.

As for Muslim "modernization theorists," representatives of "the westernized educated classes" (p. 79), Amin chooses two main examples: Muhammad Ayub Khan and Jamāl 'Abd al Nāsir, but portrays the ideas of these and other representatives of this approach as being both very similar, though varying from "liberal nationalists" to "national socialists," and unoriginal. One wonders how such individuals, as well as others briefly referred to (i.e., Kamal Ataturk) can be treated as representatives of the Islamic tradition at all, since, while they were at least nominal Muslims, they were not-as Amin makes clear-adherents of Islam as a political ideology. In fact, Amin's Epilogue concludes that these people not only "tried to copy Western models" but also "failed to deliver any good" (p. 83). He suggests that the basic fallacy of such modernization theorists was to treat Muslim countries as nation-states, which they are 
not, although he admits that the battle between nationalism and internationalism is not over in the Islamic world.

Muslim post-modernization writers, by which he means those generally "schooled in the indigenous educational system [who] reconstructed their intellectual tradition in terms understandable to persons reared in the modern intellectual climate" (p. 84), include Imam Khomeini, Sayyid Abul A'la Mawdudi, and Sayyid Qutb. All of these writers strongly condemned nationalism as un-Islamic and as an imposition of Western imperialism. Amin also briefly deals with some of their ideas on other, albeit related, issues (i.e., Qutb's stress on social justice).

What some readers will see in this volume as sketchiness others will admire as conciseness. But at many points the analysis should be expanded. Some assertions need to be substantiated, such as his statement that the "Pan-Islamic professions [of Iran's Islamic Revolution] were gradually overshadowed by the narrow sectarianism which became an increasingly conspicuous factor in shaping its policies" (p. 6).

Many of the writers from the three traditions cannot possibly be dealt with adequately in the short passages devoted to them by Amin. Their ideas evolved over time, but the author sometimes relies on a very limited selection of their writings. For example, the examination of 'Abd al Nāsir's ideas (about a page and a half) largely consists of quotes from The Philosophy of the Revolution, a pamphlet belonging to his early days in power and arguably not representative of his later speeches and interviews. In this case, Amin might have found even more basis for the "scant regard for Islamic internationalism" (p. 72), since the early inclusion of an "Islamic circle" in the Egyptian leader's identification of his country's role in the world tended to make way for a stress on participation, alongside India and Yugoslavia, in the Nonaligned Movement.

In short, this is an enlightening work and one that should be made available to students of nationalism and internationalism. I know of no other book that explicitly compares Islamic and Western traditions in such a way. It would be desirable, as I have indicated, for some of the categories used by the author to be defined more clearly (partially accomplished in the Epilogue), but overall he has done a good job of briefly analyzing the positions of so many writers. Amin also demonstrates an admirable knowledge of a diverse body of literature. Perhaps he should continue his work on this topic with the goal of eventually producing a much more thorough study, one that concentrates on Muslim writers while retaining the comparative perspective.

The long foreword by Ansari contributes significantly to the book, especially in elucidating the basic Islamic form of universalism that rejects tribal exclusivism ("asabiyah) and its modern equivalent, "the new- 
fangled nationalist ideology of a chauvinist variety" (p. xvii), but does not seek to destroy all loyalty to tribe, country, or whatever. The foreword also complements the main part of the book in other ways, as in dealing with important writers who are otherwise neglected, especially Hasan al Bannā, whose commitment to the ummah is shown not to have meant a rejection of Egyptian patriotism. Ansari calls for Muslim intellectuals to come to grips with the identity problem by examining the Qur'an and the Sunnah and relating them to "the realities of the modern age" to produce a solution that will be "authentically Islamic and contemporaneously relevant and meaningful" (p. xxviii).

Glenn E. Perry Professor of Political Science Indiana State University Terre Haute, Indiana 